\title{
PROBLEMS AND CHALLENGES OF FOREIGN LABOUR MIGRANTS
}

Manamaya Mishra*

\begin{abstract}
This paper is based on problems and challenges of foreign labour migration and the main aim of this paper is to identity the problems and challenges faced by migrant workers in the destination countries, and is based on five different manpower agencies. Information was collected through 255 respondents and respondent's household's information and descriptive and cross sectional research design and sample selection has been based on purposive method. About 37.3 percent foreign labour migrants want to go Malaysia and highest i.e. 29.4 percent respondents want to go foreign labour work by cause of poverty and 23.5 percent respondents by cause of unemployment. More than 90 percent respondents do not have any knowledge about right of foreign labour migrants. Total 163 respondents had returned from foreign labour migration; the highest 36.2 percent respondents are returned back from Malaysia. More than 55 percent foreign labour migrants stayed in foreign employment for 2-4 year and 35 percent returned migrants engaged in factory labour and 36 percent foreign labour returned migrants worked 12 hours. The highest i.e. 60.8 percent returned foreign labour migrants were sick of frequent fever and 58.8 percent foreign labour returned migrants had their treatment charge paid by their companies. Lack of information about the adequate the destination countries, poverty, unemployment, manpower agencies or agents' exploitation, discrepancy in wages before and after departure, working condition and situation in the destination countries, language, environment, out off that work permit problems are the major problems in both origin and destination place. To promote the rights of migrant's worker is major issue in present time. Foreign labour migration sending the large amount of remittance of Nepal, but they have not been able to utilize in productive sectors.
\end{abstract}

Key words: labour migration, problem, challenges and exploitation

\section{Introduction}

The United Nations Multilingual Demographic Dictionary defines migration as a form of geographic or spatial mobility between one geographical unit and another involving a

* Mrs Mishra is a PhD Scholar and Assistant Professor of Population Studies, Patan Multiple Campus, TU, Nepal 
permanent change of residence. For demographic purposes; two broad types of migrations are identified international migration and internal migration. The former refers to movement across national boundaries. It is designated as emigration from the standpoint of the nation from which the movement occurs and as immigration from that of the receiving nation. The term internal migration refers to migration within the boundaries of a given nation (Shryock and Siegel, 1976).

The conflict situation of the country has made people displaced from their usual place of residence and the alternative means of employment for displaced youth is established as foreign employment. The conflict has also limited the development activities throughout the country and expansion of industries is stopped. This situation has created more scarcity to get employment within the national border and ultimate step of the people is to go abroad for foreign employment. Though the concrete research has not been conducted yet, the young people from conflict prone areas are compelled to go for foreign employment to save their life.

Information is lacking in each and every step for potential labour migrants. Most of them are not aware where they are going, what work they have to do, the actual cost they need to spend to go for work and other social and cultural information about the country of destination. As a result, there are numerous realistic stories of the suffering of Nepalese migrant workers abroad. It is believed that Nepalese workers are accepted in East and South Asia as well as Gulf countries only because they are cheap and they do whatever job given. Most of the migrants are educated from middle and lower middle class families who go abroad with the hope of earning much within a short period. A large number work illegally (Rimal, 2004).

Government has made promotional policy regarding foreign employment but at the same time less attention has been paid to provide services and facilities in the home ground. Some of the provisions mentioned in the Foreign Employment Act-2042 are like controlling the foreign employment business rather than promotional one. Despite the great extent, international labour migration has long been paid little attention in Nepal. On the one hand the importance of international labour migration as an income source for Nepal's households and to the economy of Nepal as a whole remained officially invisible. This is due to the fact that the officially registered international labour migrants only represents a small proportion of the real number, and the value of remittance is not fully recorded in the national accounts. On the other hands, until the late 1990s, most studies of Nepal emphasized the importance of agriculture in the national economy, and the National Planning Commission (NPC) deemed agriculture to be the key to the rural development (NPC 2007). This research under the title "Migration of Nepalese for Foreign Employment: 
issues and challenges” will be conducted to evaluate the existing government policies and programmes to the regulation of international labour migration. This research will also approach to identify the major problems of international labour migrants as well as socioeconomic and demographic impact of international labour in the Nepalese context. Research question of this study are What are the national and international instruments on the issue of labour migration? And What are the main challenges on labour migration? These types of research questions are answered in this study. The aim of this paper is to find out the major issues and challenges in foreign labour migrants.

\section{Limitations}

This paper limits only on demographic and socio-economic status of 255 respondents, and limited to foreign labour migrants from different five manpower offices based on Kathmandu Districts, based on foreign labour migrants of Gulf and Malaysia only. This paper is based on aboard and returned foreign labour migrants that contracted with five different offices.

\section{Method}

This study is a cross sectional and descriptive study. This study mainly focuses on those persons who are going to be foreign labour employment and its effects on family life. Mostly qualitative and some quantitative information are collected to observe the situation of international labour migration in the Nepalese context. The source of data for this study is based on the primary and secondary sources of data and this is obtained by using direct interview among the person who is going to be foreign labour employment and also those persons who have already return and again want to go. This study takes purposively five manpower office to collect information about these people who are going to foreign labour employment. Study has taken 255 respondents within one month and use purposive sampling method (non- probability sampling). Four Manpower Company, researcher took 50 respondents and one took 55 respondents purposively. Finally, SPSS program has been used to compute the data. Frequency Distribution, Cross Table analysis is the main output of the analysis.

\section{Results and findings}

\section{Socio-DemographicCharacteristic}

This paper obtained reliable information of the foreign labour migration. This research shows that majority of foreign labour migration 25-29 years. More than 31 percent respondents are age group 25-29 years, 28.2 percent respondents are age group 20-28 years and 18.8 percent respondents are age group 30-34 years, respondents are age group 45 and above years respectively. Nearly 6 percent respondents are illiterate and the rest i.e. 94.5 
percent are literate. Out of total respondents, the highest 28.2 percent respondent have gained secondary level of education, 27.5 percent have gained primary education, 22.4 percent respondents have gained lower secondary level of education, 11.8 percent have gained intermediate education and 1.6 percent have gained SLC, Bachelor and master and above respectively. The highest i.e. 72.9 percent respondents' previous occupation to decide foreign labour migration was agriculture, 10.2 percent respondents were engaged in daily wages, 5.1 percent respondents were engaged in business 3.5 percent respondents were engaged in services and students and 3.9 percent respondents were engaged in others occupation such as poultry, tailoring, etc respectively.

\section{Causes of Foreign Labour Migrants}

The highest i.e. 29.4 percent respondents want to go foreign labour work by cause of poverty, 23.5 percent respondents by cause of unemployment, 20.8 percent respondents are caused due to debt, 16.9 percent respondents by the cause of to support child education, 7.5 percent respondents by the cause of increase of household income and 2.0 percent respondents want to go for the friend suggestion respectively.

Table 1: Percentage Distribution of Foreign Labour Migrantsby Causes of Foreign Labour Migration

\begin{tabular}{|l|r|r|r|r|r|r|}
\hline \multirow{2}{*}{ Reason } & \multicolumn{4}{|c|}{ Sex } & \multicolumn{2}{c|}{ Total } \\
\cline { 2 - 7 } & No. & Percent & No. & Percent & No. & $\begin{array}{r}\text { Percen } \\
\text { t }\end{array}$ \\
\cline { 2 - 7 } & & & & & & 23.5 \\
\hline Unemployment & 53 & 20.8 & 7 & 2,7 & 60 & 23.4 \\
\hline Debtness & 18.4 & 6 & 2.4 & 53 & 20.8 \\
\hline $\begin{array}{l}\text { To Increase household } \\
\text { Income }\end{array}$ & 18 & 7.1 & 1 & 0.4 & 19 & 7.5 \\
\hline Poverty & 72 & 28.8 & 3 & 1.2 & 75 & 29.4 \\
\hline Friend Suggestion & 5 & 2.0 & 0 & - & 5 & 2.0 \\
\hline $\begin{array}{l}\text { To support child } \\
\text { education }\end{array}$ & 38 & 14.9 & 5 & 2.0 & 43 & 16.9 \\
\hline Total & 233 & 91.4 & 22 & 8.6 & 255 & 100.0 \\
\hline
\end{tabular}

Source: Field Survey, 2014.

\section{Destination Country of Migrants}

More than 37.3 percent foreign labour migrants want to go Malaysia, 25.5 percent respondents want to go Saudi Arabia, 19.2 percent respondents want to go UAE, 12.9 
percent respondents want to go Qatar 1.2 percent want to go Kuwait and 3.9 percent want to go to other countries such as Omen, Bahrain etc.

Table 2: Percentage Distribution of Foreign Labour Migration by Destination Countries of Migrants

\begin{tabular}{|l|r|r|r|r|r|r|}
\hline \multirow{2}{*}{ Countries } & \multicolumn{7}{|c|}{ Sex } & \multicolumn{2}{|c|}{ Total } \\
\cline { 2 - 7 } & No. & Percent & No. & Percent & No. & Percent \\
\cline { 2 - 7 } & 95 & 37.3 & 0 & - & 95 & 37.3 \\
\hline Malaysia & 33 & 12.9 & 0 & - & 37 & 12.9 \\
\hline Qatar & 32 & 12.5 & 17 & 6.7 & 49 & 19.2 \\
\hline UAE & 65 & 25.5 & 0 & - & 65 & 25.5 \\
\hline Saudi & & & & & & \\
Arabia & 0 & - & 3 & 1.2 & 3 & 1.2 \\
\hline Kuwait & 233 & 91.4 & 22 & 8.6 & 255 & 100 \\
\hline Others & & 3.1 & 2 & 0.8 & 10 & 3.9 \\
\hline Total & 2014 & & & & & \\
\hline
\end{tabular}

Source: Field Survey, 2014.

\section{Receive Training, Types of Training and Orientation for Bio-data Processing}

Out of the 255 respondents, only 28.6 percent had received training and 71.64 percent have not received. Similarly, out of the 73 respondents had received training, 85 percent received safety rules work related training, 11.0 percent respondents had received language training and 4 percent respondents had received other types of training and nearly 88 percent respondents are take orientation class for the awareness for the foreign labour migration.

\section{Knowledge of Migrants Rights}

More than 90 percent respondents do not have any knowledge about right of foreign labour migrants and only 9.8 percent respondents have knowledge about foreign labour migrants. Similarly, only 9 percent respondents have knowledge about treaty of Nepal Government and ILO and 91 percent do not have knowledge. Out of the 23 respondents have knowledge about treaty of Nepalese government and ILO; nearly 35 percent respondents have knowledge about human right protection, 26.1 percent respondents have knowledge about work time and rest time and labour protection and 13 percent respondents have knowledge about work 8 hours.

\section{Returned Migrants and Duration of Stay in Foreign}

Total 163 respondents have returned from foreign labour migration, the highest i.e. 36.2 percent respondents have returned back from Malaysia, 29.5 percent respondents have 
returned from Qatar, 23.3 percent respondents have returned from Saudi Arabia and 11 percent respondent have returned from UAE

Table 3: Percentage Distribution of Foreign Labour Migrants by Duration of Stay in Foreign

\begin{tabular}{|c|c|c|c|c|c|c|c|c|c|c|}
\hline \multirow{3}{*}{ Countries } & \multicolumn{8}{|c|}{ Duration of Stay in Foreign } & \multirow{2}{*}{\multicolumn{2}{|c|}{ Total }} \\
\hline & \multicolumn{2}{|c|}{$<1$ year } & \multicolumn{2}{|c|}{$2-4$} & \multicolumn{2}{|c|}{$4-6$} & \multicolumn{2}{|c|}{6 and above } & & \\
\hline & $\mathbf{N}$ & $\mathbf{P}$ & $\mathbf{N}$ & $\mathbf{P}$ & $\mathbf{N}$ & $\mathbf{P}$ & $\mathbf{N}$ & $\mathbf{P}$ & $\mathbf{N}$ & $\mathbf{P}$ \\
\hline India & 1 & .6 & - & - & - & - & - & - & 1 & 0.6 \\
\hline Malaysia & $\begin{array}{l}3 \\
5\end{array}$ & 21.5 & 15 & 9.2 & 3 & 1.8 & 4 & 2.5 & 57 & 35.0 \\
\hline Qatar & 6 & 3.7 & 38 & 23.3 & 3 & 1.8 & - & - & 47 & 28.8 \\
\hline UAE & 1 & .6 & 16 & 9.8 & 1 & .6 & - & - & 18 & 11.0 \\
\hline Saudi Arabia & 7 & 4.3 & 20 & 12.3 & 4 & 2.5 & 5 & 3.1 & 36 & 22.1 \\
\hline Kuwait & 2 & 1.2 & - & - & - & - & - & - & 2 & 1.2 \\
\hline Others & - & - & 1 & .6 & - & - & 1 & .6 & 2 & 1.2 \\
\hline Total & $\begin{array}{l}5 \\
2\end{array}$ & 31.9 & 90 & 55.2 & 11 & 6.7 & 10 & 6.1 & 163 & 100.0 \\
\hline
\end{tabular}

Source: Field Survey, 2014.

Total 55.2 percent foreign labour migrants stayed in foreign employment for 2-4 year followed by 31.9 percent for less than one year, 6.7 percent for 4-6 years and 6.1 percent for 6 years and above respectively. Similarly, most of the foreign labour migrant's place of destination country was Malaysia and second country Qatar and third country was Saudi Arabia.

\section{Types of Job in Destination Countries and Working Hours per Day}

The highest i.e. 35 percent returned migrants engaged in factory labour followed by 17.8 percent engaged on constructions, 14.1 percent on Hotel/ Restaurants and security guards, 3.1 percent on agriculture and 13.5 percent on others types of jobs respectively. Nearly 37 percent foreign labour returned migrants worked 12 hours followed 19.6 percent worked 8 hours, 19.0 percent worked 10 hours, 16.6 percent worked 11 hours and 8 percent migrants worked 9 hours per day respectively.

\section{Sickness and Treatment}

The highest i.e. 60.8 percent returned foreign labour migrants were sick of frequent fever followed by 16.7 percent labour migrants were headache, 8.8 percent labour migrants were unconscious, 7.8 percent labour migrants were heat stress and 5.9 percent migrants were fatigue/ strain respectively. The highest 58.8 percent foreign labour returned migrants were treatment charge paid by company and self followed by 25.5 percent migrant's treatment 
charge paid by only company and 15.7 percent migrant's treatment fee paid by self respectively.

\section{Salary per Month}

Salary per month indicates the monthly salary received by the foreign labour migrants in the foreign labour market per month. Most of the foreign labour migrants are unskilled and low level of education. So, the salary of per month is not more than the others. The foreign labour migrants tend to be move new places where they can to earn more money. The salary per month is presented in the following table:

Table 4: Percentage Distribution of Foreign Labour Migrants by Salary per Month

\begin{tabular}{|c|c|c|c|c|c|c|c|c|c|c|}
\hline \multirow{3}{*}{ Countries } & \multicolumn{8}{|c|}{ Monthly Salary } & \multirow{2}{*}{\multicolumn{2}{|c|}{ Total }} \\
\hline & \multicolumn{2}{|c|}{$<20000$} & \multicolumn{2}{|c|}{$20000-25000$} & \multicolumn{2}{|c|}{$25001-30000$} & \multicolumn{2}{|c|}{$\begin{array}{c}30001 \text { and } \\
\text { above }\end{array}$} & & \\
\hline & $\mathbf{N}$ & $\mathbf{P}$ & $\mathbf{N}$ & $\mathbf{P}$ & $\mathbf{N}$ & $\mathbf{P}$ & $\mathbf{N}$ & $\mathbf{P}$ & $\mathbf{N}$ & $\mathbf{P}$ \\
\hline India & 1 & .6 & - & - & - & - & - & - & 1 & .6 \\
\hline Malaysia & 24 & 14.7 & 22 & 13.5 & 7 & 4.3 & 4 & 2.5 & 57 & 35.0 \\
\hline Qatar & 11 & 6.7 & 23 & 14.1 & 9 & 5.5 & 4 & 2.5 & 47 & 28.8 \\
\hline UAE & 4 & 2.5 & 7 & 4.3 & 5 & 3.1 & 2 & 1.2 & 18 & 11.0 \\
\hline $\begin{array}{l}\text { Saudi } \\
\text { Arabia }\end{array}$ & 8 & 4.9 & 17 & 10.4 & 6 & 3.7 & 5 & 3.1 & 36 & 22.1 \\
\hline Kuwait & - & - & 1 & .6 & - & - & 1 & .6 & 2 & 1.2 \\
\hline Others & - & - & 1 & .6 & 1 & .6 & - & - & 2 & 1.2 \\
\hline Total & 48 & 29.4 & 71 & 43.6 & 28 & 17.2 & 16 & 9.8 & 163 & 100.0 \\
\hline
\end{tabular}

Source: Field Survey, 2014.

The highest i.e. 43.6 percent of foreign labour returned migrants received NRs. 20,00025,000 salary per month followed by 29.4 percent $<20,000$ salary per month, 17.2 percent received 25,000- 30,000 salary per month and only 9.8 percent received 30, 001 and more salary per month respectively.

\section{Use of Remittance}

The flow of remittance in Nepal from foreign country is increasing in last decade. Remittance refers to that portion of migrants' earnings sent from migration destination to the place of origin. The term remittance is normally limited to monetary and other cash sent by migrant, towards to their families. In which sector the earn money is spent known as Investment sector of earned money. 
Table 5: Percentage Distribution of Foreign Labour Migrants by Investment of Earned Money

\begin{tabular}{|c|c|c|c|c|c|c|c|c|c|c|}
\hline \multirow{3}{*}{$\begin{array}{l}\text { Investment } \\
\text { Sectors }\end{array}$} & \multicolumn{8}{|c|}{ Monthly Salary } & \multirow{2}{*}{\multicolumn{2}{|c|}{ Total }} \\
\hline & \multicolumn{2}{|c|}{$<20000$} & \multicolumn{2}{|c|}{$20000-25000$} & \multicolumn{2}{|c|}{ 25001-30000 } & \multicolumn{2}{|c|}{$\begin{array}{l}30001 \text { and } \\
\text { above }\end{array}$} & & \\
\hline & $\mathbf{N}$ & $\mathbf{P}$ & $\mathbf{N}$ & $\mathbf{P}$ & $\mathbf{N}$ & $\mathbf{P}$ & $\mathbf{N}$ & $\mathbf{P}$ & $\mathbf{N}$ & $\mathbf{P}$ \\
\hline Households work & 13 & 8.1 & 23 & 14.5 & 11 & 6.9 & 3 & 1.9 & 50 & 31.4 \\
\hline Buy land & 7 & 4.4 & 9 & 5.7 & 5 & 3.1 & 6 & 3.8 & 27 & 17.0 \\
\hline To build house & 8 & 5.0 & 4 & 2.5 & - & - & 2 & 1.3 & 14 & 8.8 \\
\hline Child education & 4 & 2.5 & 2 & 1.3 & 1 & .6 & 1 & .6 & 8 & 5.0 \\
\hline To pay loan & 6 & 3.8 & 15 & 9.4 & 1 & .6 & - & - & 22 & 13.8 \\
\hline $\begin{array}{l}\text { Housework's and } \\
\text { buy land }\end{array}$ & 3 & 1.9 & 8 & 5.0 & 4 & 2.5 & 2 & 1.3 & 17 & 10.7 \\
\hline $\begin{array}{l}\text { Houseworkand to } \\
\text { pay loan }\end{array}$ & 6 & 3.8 & 10 & 6.3 & 3 & 1.9 & 2 & 1.3 & 21 & 13.2 \\
\hline Total & 47 & 29.6 & 71 & 44.7 & 25 & 15.7 & 16 & 10.1 & 159 & 100.0 \\
\hline
\end{tabular}

Source: Field Survey, 2014.

Nearly 20 percent of foreign labour migrants had invested their earnings to household works followed by 17.0 percent had invested their earnings to buy land, 13.8 percent had invested for pay loan, 13.2 percent had invested their earnings for housework and to pay loan, 11.9 percent had invested housework's and children education, 10.7 percent respondents had invested their earnings for housework's and buy land, 8.8 percent had spent for built house and only 5 percent had spent for pay loan only respectively.

\section{Challenges Faced}

Foreign labour migration is one of the challenges work itself as well as so many challenges in origin and destination. Poverty is one of the most common problems of the respondents. Both of place origin and destination is occurred problems for foreign labour migration. In origin, 51.0 percent respondents were wanted to foreign labour migration for the cause of poverty. Lack of labour for farming is one of the another challenges in origin which is 20 percent, followed by 19.6 percent respondents want to go foreign labour migration the cause of unemployment. Similarly, in the destination countries also occur so many challenges for the foreign labour migration. 
Table 6: Percentage Distribution of Foreign Labour Migrants by Challenges in Origin and Destination

\begin{tabular}{|l|r|r|}
\hline Challenges by Origin & Number & Percent \\
\hline Poverty & 130 & 51.0 \\
\hline Internal Conflict(Antarik Dondha) & 20 & 7.8 \\
\hline Unemployment & 50 & 19.6 \\
\hline No satisfaction of current Job & 51 & 20.0 \\
\hline To secure for children's Career & 4 & 1.6 \\
\hline Total & 255 & 100.0 \\
\hline Challenges by Destination & & 30.7 \\
\hline Risk of Health (building construction ) & 50 & 33.7 \\
\hline Job did not get as Agreement Paper & 55 & 9.2 \\
\hline Did not pay salary in time & 15 & 26.4 \\
\hline Did not provide Lodging and fooding & 43 & 100.0 \\
\hline Total & 163 & \\
\hline
\end{tabular}

Source: Field Survey, 2014.

The highest (33.7 \%) respondents faced the problems job did not match the agreement paper, nearly 31 percent respondents faced the health risks: in specially building construction sectors. Similarly, 26.3 percent respondents' problems companies did not provide lodging and fooding and 9.2 percent respondents said did not pay salary in time.

\section{Conclusions}

The foreign labour migration is a burning issue in Nepal because large numbers of active population are migrated day by day to the Gulf countries and others countries. Uneducated and unskilled population's migration flow to Gulf countries where so many dangerous works such as construction sectors, farming sectors. Most of Nepalese youth are going due to various causes in Nepal. The major causes, problems and challenges to Nepalese foreign labour migration are lack of adequate law and information about destination countries, potential labour face financial problems, lake of adequate killed, training and discrepancy in wages before and after departure. Many manpower agencies or agents are accused of exploiting potential migrants.

Lack of employment opportunities in the remote areas is push factors of young people for emigration. Low level of education, unskilled labour, lack of vocational training and language skills are the great challenges for foreign labour employment. Local broker/ agent and man power agencies carelessness has been creating problems for foreign employment. 
Some illegal channel plays vital role to fraud the migrants but now a day as well, there is no any department and strong policy or law to punish such illegal cannels. To solve the problems and challengers which are facing by foreign labour migrants in host country, out of government should make appropriate and strong policy to solve such problems.

\section{REFERENCES}

IOM, (2004). International Migration Vol. 42(5) (Geneva: IOM)

Rawat. J.K. (2016). Issues and Challenges of Foreign Labour Migrants: AStudy Based on Five Different Manpower Office, Kathmandu District, Central Department of Population Studies (CDPS), Tribhuvan University (TU)

Ministry of Labour and Employment, (2013/2014). Labour Migration for Employment: A Status Report for Nepal: 2013/2014. (Kathmandu, Government of Nepal).

Ministry for Labour and Transport Management, Labour and Employment Promotion Department, (2003). Labour Market Information Bulletin, Year 2. No. 2, (Kathmandu: Labour and Employment Promotion Department)

NPC, (2007). Tenth Plan, 2007-12, Kathmandu: NPC,

Population Council, (2001). “The US National Intelligence Council on Growing Global Migration,” Population and Development Review, 27(4)

Population Council, (2003). The United Nations on Levels and Trends of International

Rimal, Bishnu, (2004). “Migrant Workers a Snap Shot”, (General Federation of Nepalese Trade Unions (GEOFONT) (Kathmandu: 2004)

Shryock, Henry J., J.S. Siegel, (1971). The Methods and Materials of Demography (Washington: Government Printing office), 349-405. 